\title{
The stock market bubble of 1929: evidence from closed-end mutual funds
}

\section{Citation}

De Long, J. Bradford, and Andrei Shleifer. 1991. The Stock Market Bubble of 1929: Evidence from Closed-End Mutual Funds. The Journal of Economic History 51, no. 3: 675. doi:10.1017/ s0022050700039619.

\section{Published Version}

doi:10.1017/S0022050700039619

\section{Permanent link}

http://nrs.harvard.edu/urn-3:HUL.InstRepos:30703980

\section{Terms of Use}

This article was downloaded from Harvard University's DASH repository, and is made available under the terms and conditions applicable to Other Posted Material, as set forth at http:// nrs.harvard.edu/urn-3:HUL.InstRepos:dash.current.terms-of-use\#LAA

\section{Share Your Story}

The Harvard community has made this article openly available.

Please share how this access benefits you. Submit a story.

Accessibility 


\title{
The Bubble of 1929: Evidence from Closed-End Funds*
}

\author{
J. Bradford De Long \\ Harvard University and NBER \\ Andrei Shleifer \\ University of Chicago and NBER
}

February 1990; revised July 1990

\footnotetext{
*We would like to thank Stefan Krieger for excellent research assistance and thoughtful discussions. We would also like to thank David Cutler, Lawrence Summers, Robert Vishny, and Robert Waldmann for helpful comments, and the National Science and Russell Sage Foundations for financial support.
} 


\section{Introduction}

The sharp rise and subsequent crash of stock prices in 1929 is perhaps the most striking episode in the history of American financial markets. The nominal S \& P composite index rose sixty-four percent from January 1928 to September 1929, fell thirty-three percent from September 1929 to December 1929, recovered about halfway to its 1929 peak, and then fell again to a low point in the summer of 1932 sixty-six percent below its December 1929 level and seventy-seven percent below its September 1929 average (see figure 1).

Figure 1

S\&P Composite Nominal Stock Price Index

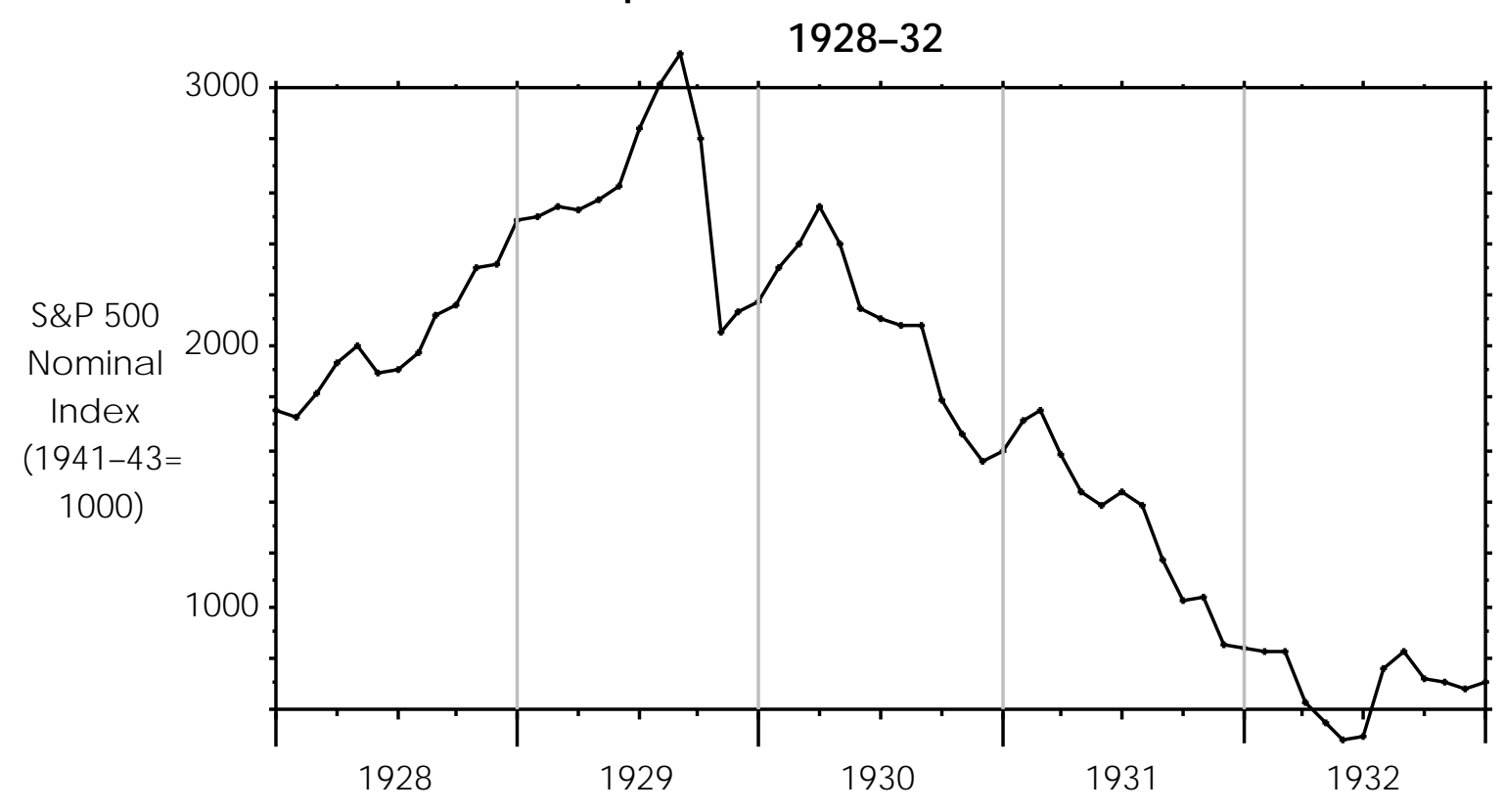

Some observers have interpreted this price pattern as reflecting changing fundamentals in the economy. Irving Fisher (1930), for example, argued throughout 1929 and 1930 that the high level of prices in 1929 reflected an expectation that future corporate cash flows would be very high. Fisher saw this expectation as warranted after a decade of steadily increasing earnings and dividends, rapidly improving technologies, and monetary stability. According to this interpretation of 1929, the runup of stock prices before the crash reflected shifts in expectations of the future that were ex post faulty but ex ante rational. The crash and the subsequent slide of stock prices then reflected a rational, and in this case an ex post correct, revision of beliefs as investors recognized the approach of the Great Depression and the end of the Roaring Twenties.

Other students of the Great Crash, notably Galbraith (1954), have argued that even though 
fundamentals appeared high in 1929 the stock market rise was clearly excessive. Galbraith cites margin buying, the formation of closed-end investment trusts, the transformation of financiers into celebrities, and other qualitative signs of euphoria to support his view. Over the past three decades, Galbraith's position has lost ground with economists, and especially financial economists, as the efficient market hypothesis has gained.

Much of recent work sides with Fisher's interpretation of 1929. Sirkin (1975), for example, examines the revisions of long-run growth forecasts required for shifts in stock yields in 1929 to reflect shifts in perceived fundamental values. He finds that compared to actual post-World War II yields and stock returns the implied growth rates of dividends are quite conservative, and in fact lower than post-World War II growth rates. Santoni and Dwyer (1990) fail to find evidence of a bubble in stock prices in 1929. White (1990a and 1990b) saw "qualitative evidence... [that] favors the view that a bubble was present," but cautioned that "[t]he failure of dividends to keep pace with stock prices does not...necessarily imply the existence of a bubble," and thought it unlikely at the time of his writing that convincing quantitative estimates of overvaluation can be made. ${ }^{1}$

Along similar lines, Barsky and De Long $(1989,1990)$ argued that if the long run growth rate of dividends is unstable then large swings in stock prices, such as those of the 1920's and 1930's, will be the rule rather than the exception. In Barsky and De Long's model, investors update their beliefs about the long-run growth rate of dividends in response to changes in current dividends; hence warranted valuations can change dramatically in response to small changes in dividends. They find that stock prices appear, if anything, less sensitive to changes in current real dividends in the late 1920's and the early 1930's than in the remainder of the twentieth century.

In this paper we present evidence that a substantial component of the rise in stock prices up to and fall of stock prices away from September of 1929 was in fact excessive, and not based on rational revisions of warranted valuations. Our evidence is based on an analysis of the prices, discounts from net asset values, and new issue volumes of closed-end mutual funds during and after 1929. We estimate that at the peak the stock index was more than one-third above its fundamental value. Using a different souce of information-the interest rates charged on brokers' loans-Rappoport and White (1990) have produced a similar estimate: they estimate under the assumption that lenders were risk neutral that at the market's peak those banks making

\footnotetext{
${ }^{1}$ White saw this lack of quantitative estimates of the 1929 bubble as a serious deficiency, and he and Rappoport have explored the possibility of using information from the brokers' loan market to estimate the bubble (Rappoport and White, 1990).
} 
brokers' loans thought the market overvalued by one-half.

In earlier work, De Long, Shleifer, Summers, and Waldmann (1990) and Lee, Shleifer and Thaler (1989) have focused on closed-end funds as a measure of the sentiment of individual investors. Closed-end funds do not give investors direct claims on the assets of the fund. Investors desiring to liquidate cannot return their shares to the fund and trigger a partial liquidation of its portfolio, but must instead sell their shares to other investors. Because a closed-end fund is a company that has shares of other companies, one can measure its fundamental exactly: it is the market value of the securities it holds-the net asset value.

It is well-known that closed-end funds sell for prices that often differ from net asset values. In fact, in the post-World War II period funds have tended to sell at discounts from their net asset values. De Long et $a l$. present a theory of the pricing of closed-end funds in which the discount on these funds is a measure of an irrational investor sentiment factor. Lee et al. present some evidence consistent with this theory.

In this paper, we begin with the conclusion of this earlier work that discounts on closed end funds are a measure of the sentiment of individual investors toward stocks, and we investigate whether stock prices in 1929 were excessive. We estimate that about a fifth of the runup in stock prices from 1927 to 1929 and about half of the fall in stock prices from 1929 to 1931 were due to shifts in irrational investor sentiment and not to rational revisions of estimates of fundamental values.

Our conclusion is based on three pieces of evidence. First, the median closed-end fund premium in the third quarter of 1929 was about 50 percent. Such high premia on average have not since been achieved in the United States. Second, new closed-end fund issues in the third quarter of 1929 reached their highest level ever, and according to the Commercial and Financial Chronicle amounted to a billion dollars in the two months of August and September of 1929. In the theory of De Long et al. (1990) both high premia and large volumes of new closed-end fund issues are evidence of excessive investor optimism. This amount is equivalent in purchasing power to perhaps nine billion of today's dollars, and bore the same proportion to the U.S. economy then that 55 billion dollars would bear today.

Our third piece of evidence uses the observation of Lee et al. that cosed-end fund premia reflect the sentiment of individual investors. In the 1920's institutional investors barely existed, and individual investors dominated the holding and trading of all stocks. Individual investor sentiment should then have affected both closed-end fund prmia and stock prices. In fact, during this period, changes in the median discount on closedend funds are strongly correlated with changes in stock prices.

We take this evidence further by constructing an alternative measure of investor sentiment equal to the 
difference between the S\&P stock index and an estimate of fundamentals due to Barsky and De Long (1990). Barsky and De Long's assumptions about fundamentals are designed to make fundamentals volatile, and so provide a fundamentals-based accounting for the large bull and bear swings in stock prices in the twentieth century. Their framework provides for a larger increase in warranted fundamental values in 1929 than any other available rational model of the stock market. Yet their measure is not a perfect fit, and substantial deviations of actual prices from the Barsky and De Long warranted values remained. These deviations are closely correlated with the average premium or discount on closed-end funds. The measure of sentiment from closed-end funds is not only correlated with stock prices but closely parallels the independently constructed measure of sentiment from Barsky and Delong (1990). This evidence corroborates the interpretation of 1929 stock prices as reflecting in part excessive investor optimism.

The next section briefly reviews earlier work that uses closed-end fund discounts as a measure of investor sentiment. The third section presents our evidence on closed-end fund discounts. The fourth section analyzes the correlation between the median closed-end fund discount and stock prices relative to "fundamentals." The fifth section briefly addresses the question of whether the bubble of 1929 had effects on the real economy. Section six concludes.

\section{Disc ounts on Closed End Funds as a Measure of Investor Sentiment.}

The closed-end fund anomaly refers to the empirical finding that closed-end mutual funds often trade at prices substantially different from their net asset values — the value of the securities they hold (Malkiel, 1987). When they are issued, closed-end funds typically sell at premia to net asset value. Without such premia, funds could not be organized without a loss to the organizers. But after issue fund share prices typically move to a discount to net asset value. The discounts to net asset values fluctuate over time, and changes in discounts are strongly correlated across funds. Occasionally discounts turn into premia. By and large, funds in the post-World War II period have sold at less than the market value of their holdings, with the median fund fluctuating between a premium of five and a discount of twenty-five percent (see Lee et al., 1989). Figure 2, using data from Lee et al., plots post-WWII premia and discounts for closed-end funds.

Many standard explanations of the closed-end fund puzzle, such as illiqudity, taxes, and agency costs, have been shown to be inconsistent with the data (see Lee et al., 1989). De Long et al. (1990) offer an alternative explanation of the puzzle which is not consistent with efficient markets. In their model there are 
two types of investors: noise traders whose demand is determined in part by irrational changes in their sentiment toward some securities, including closed-end funds, and rational investors who are not influenced by irrational sentiment factors. In the case of closed end funds, noise traders are probably the individual investors who hold and trade most of the funds' shares. When noise traders are optimistic, they increase their holdings. Rational investors accomodate this demand, reduce their own holdings, and if necessary go short. Noise traders' optimism drives up the prices of closed end funds relative to their net asset values, and discounts shrink or turn into premia. Conversely, noise trader pessimism causes them to reduce their holdings of the funds and other assets they trade. Since rational investors must hold more of the funds and bear more investor sentiment risk, they require higher expected returns, and so the discounts widen.

Figure 2

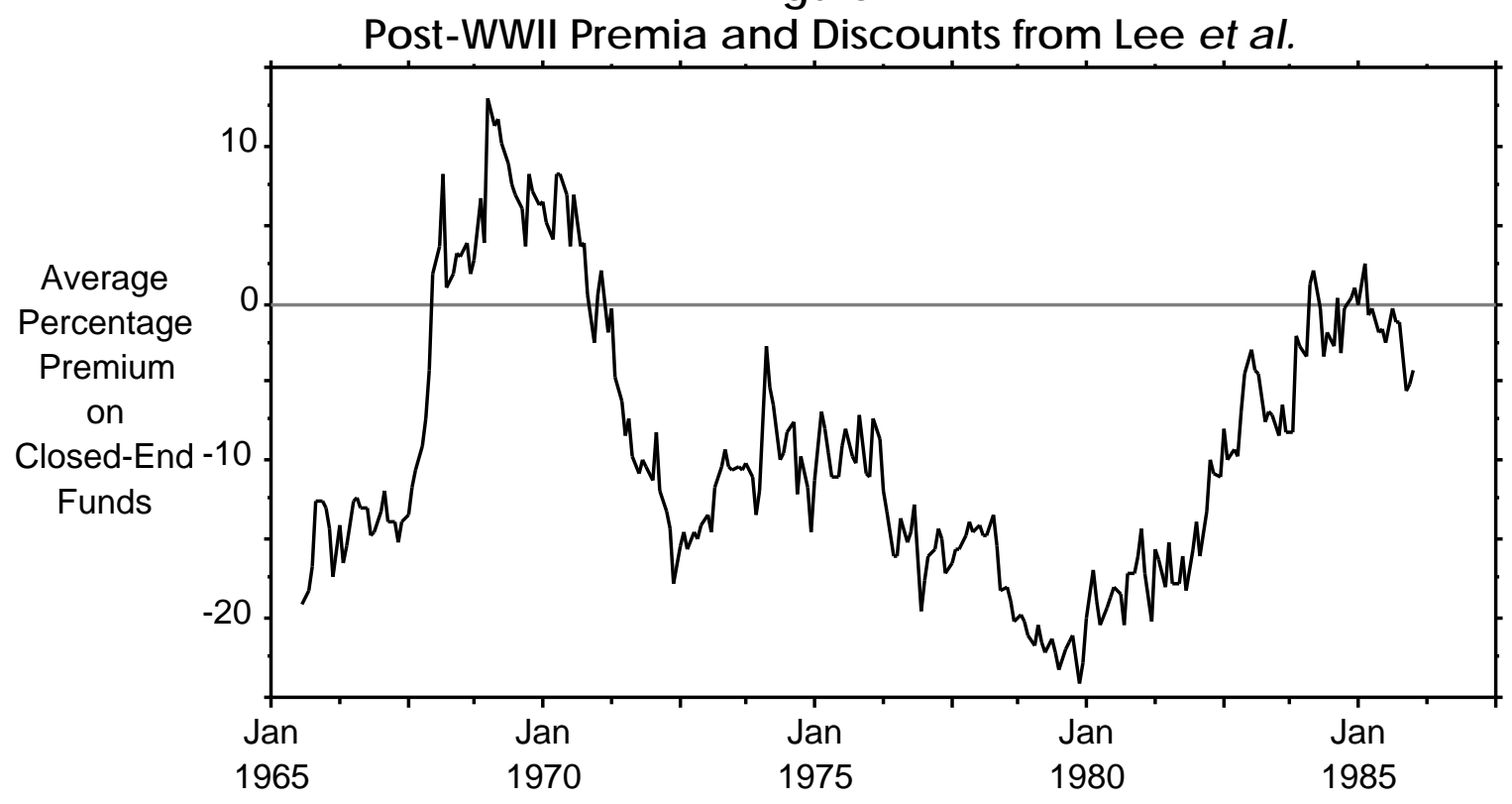

For this theory to hold together, arbitrage by rational investors must not eliminate the discounts on closed-end funds. Why don't rational investors buy funds selling at discounts, sell short their underlyingportfolios, and ensure themselves a perfectly hedged profit? De Long et al. attribute the failure of arbitrage to the unpredictability of changes in investor sentiment and the finite horizons of rational investors. An investor who buys a fund and shorts its portfolio runs the risk that at the time he liquidates his position sentiment about funds will have turned more negative, and so his attempted arbitrage trade will result in a loss. This risk from changes in investor sentiment keeps rational investors from trading to eliminate the 
discounts. However, it deters arbitrage only if it affects the prices of a large number of securities, and so cannot be hedged. Investor sentiment risk must therefore be systematic for the theory to hold. And if it is, it will be priced in equilibrium.

The implications of this theory of closed-end fund discounts have been examined by Lee et al. First, investor sentiment imposes an additional source of risk on holdings of closed-end funds that investors must be compensated for bearing. In other words, closed-end funds must on average sell at a discount to their net asset values, which is indeed the case. Second, for the investor sentiment factor to be priced it must affect all closed-end funds, and so discounts on funds must fluctuate together. Lee et al. have documented this for U.S. funds since 1960. Third, the theory predicts that new closed-end funds will be started when noise traders are excessively bullish about some set of assets including the funds, and so are willing to buy bundles of assets at a premium over net asset value. Rational investors start closed-end funds when they can sell overpriced bundles of assets to people who overvalue them. Lee et al. find that new funds do start (at a premium of course) when seasoned funds sell at premia or at discounts that are small by historical standards.

The final, and perhaps the least obvious, prediction of the theory is that there must be securities other than closed-end funds which are affected by the same systematic investor sentiment factor. If this were not the case, investor sentiment would be an idiosyncratic factor affecting demand for closed-end funds only, and would not be priced in equilibrium. Lee et al. show that changes in discounts are correlated with returns on smaller stocks, which happen to be a class of securities held largely by individuals. This suggests that since World War II fluctuations in closed-end fund discounts, and the existence of the average discount, may be driven by the individual investor-sentiment factor that affects the post-World War II pricing of smaller stocks.

The consistency of the data with the theory suggests that the average discount on closed-end funds can be a useful measure of investor sentiment. We therefore use this measure to assess the role of investor sentiment as opposed to fundamental news in the boom of 1929.

\section{Evidence}

This section presents evidence on the behavior of closed-end funds around 1929. We first examine the evolution of the discounts and premia on closed-end funds during the late 1920s and the early 1930s. Next, we outline the pattern of new issues of closed-end funds over this period. 


\section{Sources of Data on Closed-End Fund Discounts}

In the post-World War II period, data on the net asset values—and thus on the premia or discounts—of closed-end fund shares are printed weekly in the financial press. However, until the middle of 1930 there is no systematic reporting of the net asset values of closed-end funds. During the 1920's, closed-end fund promoters argued that a closed-end fund has tangible assets—its portfolio—and intangible assets—-the skills of its professional management. If a fund revealed its portfolio, they argued, its managers would be unable to earn a fair return on their expertise: investors would simply trade to copy the fund's portfolio and so avoid paying the management fee. Because closed-end fund promoters in the 1920's looked on a fund's portfolio as a trade secret, portfolios were rarely published and net asset values rarely calculated (see Becker, 1930).

After October 1929 closed-end funds hastened to publish their portfolios as soon as fund share prices fell below net asset values to convince investors that the fund was still solvent after the crash. Data on closedend fund discounts from the fourth quarter of 1929 on are, therefore, often available. We rely on Barron's, the Commercial and Financial Chronicle, Commerce and Finance, and Keane's Investment Trust Monthly Magazine for calculated discounts and premia on closed-end funds after the end of 1929.

In the third quarter of 1929, three types of events seem to trigger a closed-end fund's publication of its portfolio or the current net asset value of its shares. The first is listing on the New York Stock Exchange. From the summer of 1929 on, the Exchange is willing to add closed-end funds to its listings, or to continue to list funds, only if they make their portfolios public (NYSE, 1929). We have taken our sample of funds revealing their net asset values because of NYSE listings from the Commercial and Financial Chronicle, and contemporaneous security price observations from the New York Times.

The second is the starting-up of a new closed-end fund. Its net asset value is simply the initial capital stock subscribed because the firm has had no chance to make trading or investment profits; the discount or premium can then be inferred from the share price. Lee et al. have demonstrated that premia on newly issued funds are substantially correlated with premia on seasoned funds after 1960. Our sample of new funds and their prices is from the Commercial and Financial Chronicle.

The third type of event is when a closed-end fund's shares go to a discount from net asset value. This often triggers publication of the fund's portfolio to convince investors that the fund is underpriced and to try to boost the stock price. When other closed-end funds' managements had positive values on the stock market, it seemed unreasonable to fund managers that their funds should sell at a discount. We think, therefore, that funds that publish their portfolios before October of 1929 do not reflect the average premium or discount; 
such funds are drawn from the lower tail of the distribution. We have one such fund in our sample. The American-European Securities Fund published its portfolio in December of 1928 and December of 1929. We have traced the net asset value of the December 1928 portfolio forward, and the value of the December 1929 portfolio back. The two portfolios have similar net asset values, and we use a weighted average to construct monthly premia and discounts for American European Securities during 1929.

We have also found retrospective data from various sources on closed-end fund discount and premia before 1929. Post-1929 publication of net asset value data was sometimes combined with publication of pre1929 net asset value data as well. These observations are also included in our data base.

\section{The Evolution of Discounts: Quantitative Evidence}

Figures $3 \mathrm{a}$ through $3 \mathrm{c}$ present our observations on discounts and premia on closed-end funds. Funds selling for premia of more than 175 percent above net asset value are omitted. There are thirteen such in our sample_-six of them during 1929, and seven during 1932 and 1933. These premia occur because highlyleveraged funds with large debt liabilities find the value of their portfolios shrinking to the face value of their obligations. In such a case, high premia exist because the common stock—of zero immediate liquidation value-retains an option value. Similarly, we omit twenty-six observations of funds with common stock that have negative net asset values during 1932 and 1933. The appendix presents the funds, asset values, premia or discount, and sources for our observations before the beginning of 1930, after which the number of data points becomes much larger.

Figure 3a presents the premia on seasoned funds for which we could obtain data, excluding American European Securities, which is treated separately below. We use the median premium to measure the central tendency of the premia because it is insensitive to the very large outlier premia in the upper tail of the distribution. In the first quarter of 1929, the median seasoned fund sells at a premium of 37 percent. In the third quarter of 1929, this premium rises to 47 percent. However, by December 1929 a substantial majority of seasoned funds sell at discounts, with the median discount at 8 percent. 
Figure $3 a$

Premia and Disc ounts on Seasoned Funds

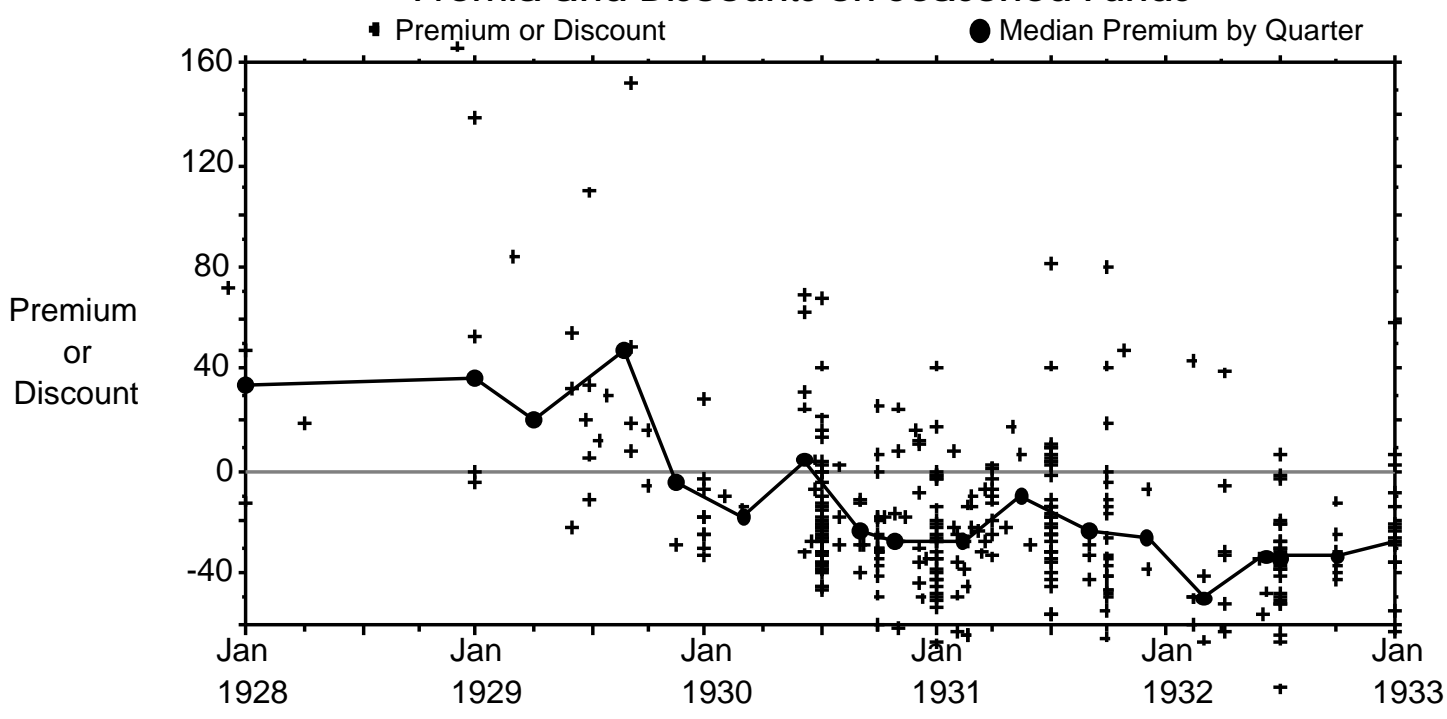

Figure $3 b$

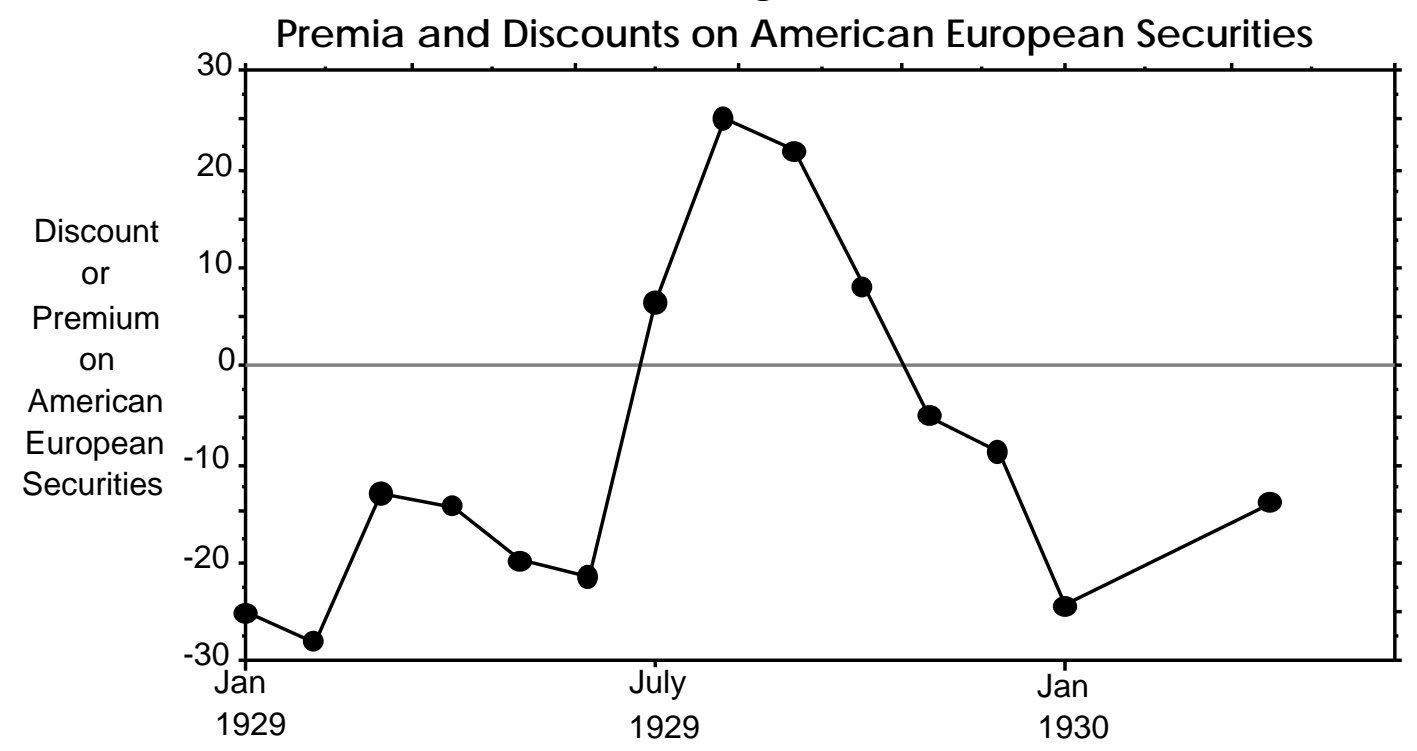

Figure $3 c$

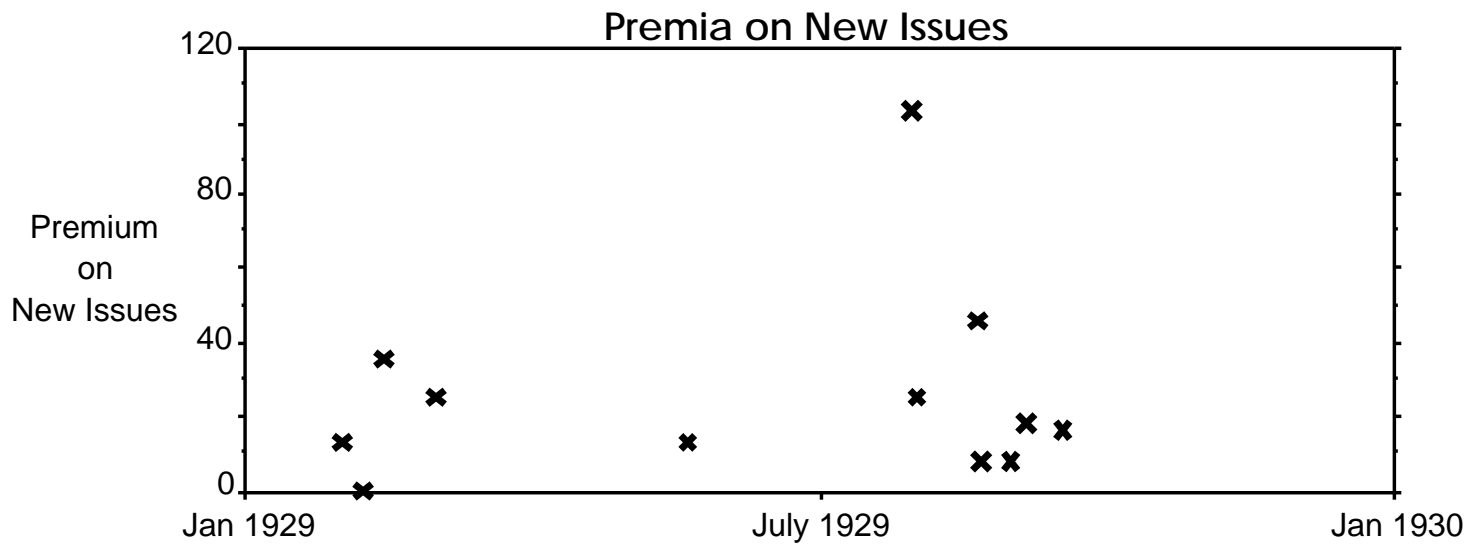

Throughout the early 1930's the median seasoned closed-end fund sells at a substantial discount. After 
1930, shifts in the average closed-end fund discount are roughly in phase with shifts in the stock market. Periods during the 1930-1933 slide which see stock prices decline most steeply tend to also see a widening of closed-end fund discounts; by contrast, periods that see stock prices falling only slowly or steady tend to see a narrowing of discounts. Although there is considerable cross-sectional variation in discounts, figure 3a makes it clear that discounts on different funds move together, as the theory of investor sentiment predicts and as the post-1960 data show.

\section{Sluggish Reporting}

The evidence on median premia suggests very large premia in the third quarter of 1929, indicating excessive investor optimism. There may be several problems with these data. First, seasoned funds might be entering our sample because their premia are unusually large, and for this reason are reported in the sources we use. Second, a similar pattern to our findings could be accounted for by sluggish adjustment of reported net asset values. During a sharp market rise the measured premium will rise if the reported net asset value does not increase while the price does.

Some additional evidence can be brought to bear on these objections. American European Securities is a fund that is likely to have smaller premia than the median, because it published its portfolio in 1928 and 1929 at least in part to call attention to its management's view that it was undervalued in the market. Figure $3 \mathrm{~b}$ presents the premia on this fund. At the beginning of 1929, the American European Securities Fund sells at a discount of more than 20 percent, even when there is no evidence that other funds sell at discounts. By the third quarter of 1929, American European Securities sells at a premium of 20 percent; while this is not as high as the median premium, it is large both by the standards of American European Securities' previous price relative to net asset value and by the standard of post-WWII experience. This premium has turned back into a discount by the end of 1929. The fact that a fund with premia small relative to those of other funds nevertheless sells at a premium of 20 percent in the third quarter of 1929 is strong evidence that large premia were the rule, not the exception.

Our interpretation of procyclical closed-end fund premia is that investors overreact to good news, and therefore periods of high fundamentals are also periods of excessive optimism. This optimism is reflected, in particular, in high premia on closed-end funds. In principle, our empirical finding could also result from sluggish adjustment of printed net asset values to the true current market prices. If net asset values fail to move when the market moves, premia will widen precisely when the market rises, producing our finding. 
With respect to this sluggish reporting objection, four points should be noted. First, Lee et al. fail to find evidence of sluggish adjustment of net asset values in post-1960 data. Second, the calculated premia and discounts on American European Securities are made from their reported holdings on specific dates, and thus are not sluggish. Third, for the premia we observe to be spurious, net asset values must fail to adjust at all in spite of large market movements - they must be very stale, and not just sluggish.

Fourth and most important, figure $3 \mathrm{c}$ shows evidence of large premia on newly-issued closed-end funds at the time their trading prices are first quoted. The first quote usually occurs within a day or two of issue. In the summer of 1929 the median newly-issued fund sells at a premium of 25 percent. In the winter of 19291930 no new fund issues are to be found. Evidence on newly issued funds should be viewed in conjunction with the other evidence, since by itself it might be misleading. Newly issued funds might be dressed up for new investors, and so their premia might overstate the typical premium. Alternatively, new funds might be quoted at prices available to "insiders" only and so their premia might understate the typical premium.

Taken together, the evidence on seasoned funds, American European Securities, and newly-issued funds all point to large premia in the third quarter of 1929. We interpret these premia as evidence of investor overoptimism. The change from a 47 percent premium in the summer of 1929 to a 25 percent discount in the summer of 1930 imposed a negative 72 percent return to holders of seasoned closed-end funds for the year, over and above the 12 percent or so real negative return from July 1929 to July 1930 experienced by the fund fundamental values as a result of the stock market crash. The relative fall in the value of closed-end funds in 1929-30 was thus much larger than the relative fall in the value of stocks of operating companies.

\section{The Evolution of Discounts: Qualitative Evidence}

The quantitative evidence on discounts before the crash of 1929 is backed up by less formal, qualitative evidence as well. The most significant further evidence that premia must have been large in the third quarter of 1929 is the massive issue of new funds during this period which we document below. But there is other evidence as well. The Magazine of Wall Street, for example, recommends the following guidelines for selecting closed end funds on September 21, 1929:

Shares of an investment company capitalized with common stock only and earning 10 percent net on invested capital might be fairly priced at 40 percent to 50 percent in excess of share liquidating value. If the past record of management indicates that it can average 20 percent or more on its funds, a price of 150 percent to 200 percent above liquidating value might be reasonable.... To evaluate an investment trust common stock, preceded by bonds or preferred stock, a simple rule is to add 30 
percent to 100 percent, or more, depending upon one's estimate of the management's worth, to the liquidating value of the investment company's total assets.

This recommendation, made only a month before the Great Crash, assumes as a matter of course that funds should be selling at large premia; managers' ability to pick stocks is thought to multiply the value of the fund by a factor ranging from $3 / 2$ to 3 . Moreover, investors are advised to chase the trend, to load up on funds whose assets in the past have shown good performance on the theory that their managers are the best.

Such blithe assumption that the intangible skill of a fund's management should lead investors to value it as worth far more than its net assets could only be sustained if closed-end funds were typically selling at high premia over net asset values. The paragraph quoted above would seem eccentric in the post-World War II period when funds have typically sold at discounts. Academics and analysts who recommend closed-end funds in the post-World War II period stress how the existing discount gives purchasers greater fundamental returns for an equal initial investment; they do not stress the trading skill of the fund's managers or argue that it "ought" to sell for half again its net asset value (Malkiel, 1987).

Investment analysts trying to direct investors away from closed-end mutual funds also wrote as if such funds sold at far above net asset value in the third quarter of 1929 and earlier. McNeel's Financial Service in Boston, for example, ran a series of large advertisements in 1929 issues of Commerce and Finance, asking (in bold type), ”Are Your Paying \$800 for General Electric When You Buy Investment Trusts?” These advertisements noted that investment trust stocks are "in many instances selling for two or three times...asset value. They are issued to the public and almost immediately quoted double or treble the issue price." They asked whether it really made sense for investors to be "paying double or treble the current prices for high grade securities."

In early 1930 Charles Keane, who had for several years been compiling information sent to him by individual closed-end funds into his Keane's Manual of Investment Trusts, shifted to publishing Keane's Investment Trust Monthly. This magazine was written by and for managers in and promoters of mutual funds, predominantly the closed-end funds that then had the largest market share. Pre-crash editions of Keane's Manual of Investment Trusts, and pre-crash "Investment Trust" columns in Wall Street newspapers give much space to funds selling at premia from net asset values. Periodicals might bias their reporting toward the more spectacular funds selling at unusually high premia, but there is internal evidence in Keane's Investment Trust Monthly that the emergence of discounts on the majority of funds after October 1929 was a new development. The writings in Keane's Investment Trust Monthly from early 1930 on show repeated surprise and 
puzzlement at the fact that closed-end funds are selling at discounts from net asset values. A range of commentators in Keane's, just like the ones in the Magazine of Wall Street, argue that a closed-end fund has tangible assets - the stocks and bonds in its portfolio — and intangible assets— the skills of its managers at picking stocks. Its tangible assets are worth their current market values; its intangible assets have a value as well. They conclude that closed-end funds should always sell at a premium to their net asset values and leave no doubt that they view discounts on these funds as a new as well as puzzling phenomenon.

Keane himself writes (May 20, 1930) that there are three reasons for a closed-end fund to sell at a discount from its net asset value: management incompetence, management corruption, or a fear that the fund has undertaken unfavorable speculations. At the beginning of 1930 managers and analysts writing from the Investment Trust Magazine advance the hypothesis that discounts on closed-end funds have emerged because investors fear that funds were highly committed and leveraged during the crash, and begin to advocate publication of portfolios—even though this will, they say, allow for free-riding on managerial expertise- to reassure investors. Indeed, funds begin to publicize their holdings in mid-1930 with the express intent of reassuring investors that they still had tangible assets after the crash, and so strengthen demand for their stock.

In sum, the evidence leaves no doubt that closed end funds sold at very large premia to net asset value in the third quarter of 1929. In the model of De Long et al., this is evidence of fundamentally unjustified noise trader optimism of a large magnitude. The implication is that other securities were also selling for more than their fundamental values. Even though the rational estimation of fundamentals was extremely high in the fall of 1929, the pattern of closed-end fund premia suggests that stock market values were even higher than those estimates.

\section{New Issues of Closed-End Funds}

Closed-end funds can only be issued at a premium to net asset value. The assets of the fund must be bought with the proceeds of the sale. And there must be enough left over to induce promoters to set up the fund. According to De Long et al.'s theory, closed-end funds will be issued when investors are excessively bullish as entrepreneurs attempt to profit from this excess bullishness by repackaging stocks into funds. Goldman Sachs partner Sydney Weinberg was asked why his company had formed so many closed-end funds so rapidly in 1929. His reply was: "Well, the people want them" (see Investment Trusts and Investment Companies). Lee et al. report that in the post-1960 period new closed-end fund issues are concentrated in times when seasoned funds are selling at premia. This suggests that the same factor that causes seasoned 
funds to sell at a premium also creates the demand for the new funds. We have establisheds in figure 3a-c above that both new and seasoned closed-end funds sold at large premia in the summer of 1929 . We now consider new fund issues in 1929.

Almost $\$ 1$ billion of new fund equity (including preferred shares) was issued in the third quarter of 1929, almost $\$ 1.9$ billion for all of 1929, and \$3.4 billion since the funds started being issued in 1923-24. Relative to the size of the United States economy then, new closed-end fund issues in the third quarter of 1929 were as large a proportion of GNP as a sum of $\$ 55$ billion would be today; since 1929 the price level has risen by a factor of nine, real GNP has risen by a factor of six, and the proportion of stock market value to GNP has remained about constant.

Figure 4

Number and Volume of New Closed-End Fund Issues, 1928-1929 (Including New Issues by Seasoned Funds)

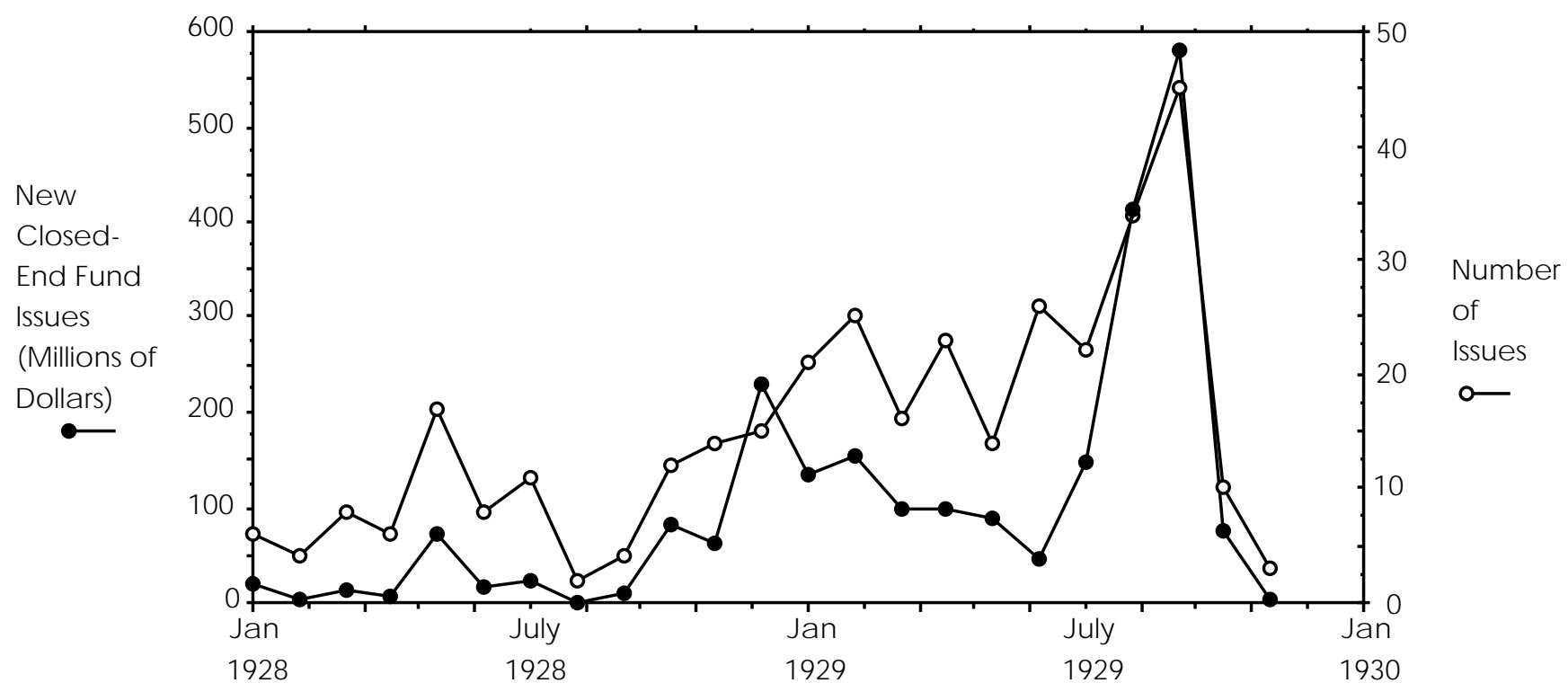

Figure 4 presents the time pattern of the number and dollar volume of new issues by closed-end funds (including expansions of preferred stock by seasoned funds) during 1928 and 1929, which saw the issue of 70 percent of all funds issued in the 1920's. Both series begin increasing toward the end of 1928, and reach their maximum in August and September of 1929. After that they fall off: no closed-end funds are started in the 1930's, although a few funds make small issues of preferred stock during the spring 1930 rally. The evidence confirms that new issues reached astronomical proportions at the same time that the premia on closed-end funds reached their peak. This fits the investor sentiment theory, in which closed-end funds are created by 
rational investors to take advantage of noise trader overoptimism.

New issues were typically issued to insiders or to favored customers at prices slightly above the net asset value, but many of them quickly rose to a large premium. For example, Lehman Brothers Corporation was significantly oversubscribed at $\$ 104$ per share that bought $\$ 100$ in assets (but note that its management contract gave 12 1/2 percent of profits to Lehman Brothers as a management fee; perhaps its true net asset value was $\$ 88$ ). It immediately rose to $\$ 126$ per share in open trading. The organizers collected not only $\$ 4$ per share and large future management fees, but they were also significant initial investors at more favorable terms than those available to the public and they reserved the right—not valuable if the fund is selling at a discount, but valuable if it selling at a premium - to take their fee in the form of new shares purchased at current net asset value.

If closed-end fund premia reflect excessive noise trader optimism, funds will pyramid on top of one another. If each fund can be sold for 50 percent more than its net asset value, then promoters can more than double their profits by establishing a fund that owns funds that hold stocks, rather than just establishing funds that hold stocks. Although detailed evidence on this is not available, this prediction is confirmed by one of the largest funds: the Goldman Sachs Trading Company. The Goldman Sachs Trading Company was a closed end fund organized in December 1928 with a net asset value of around \$100 million. In 1929 one its largest holdings was the Shenandoah Corporation-another closed-end fund organized by Goldman Sachs. Nor is this all. In the same year, Shenandoah organized a new closed-end fund called the Blue Ridge Corporation and became a large investor in its stock. All these funds traded at premia; at the top of the pyramid, the Goldman Sachs Trading Company traded at a premium to a premium to a premium to net asset value. It is hard to justify these structures other than as attempts to part fools from their money.

\section{The Closed-End Fund Disc ount and the Aggregate Market}

\section{The Correlation of the Fund Discount and the Aggregate Market}

The rise in the median closed-end fund discount from 1928 to 1929, and the fall in the discount after 1929, are correlated with the level of the aggregate stock market. Figure 5 plots movements in the log of the $\mathrm{S} \& \mathrm{P}$ composite index against the median closed-end fund discount. Using quarterly data for the period 1928:IV to 1932:IV, a regression of the S\&P index on the median fund discount produces a slope of 1.4 (with a t-statistic of 4.3, but a Durbin-Watson of 0.9 ), an $\mathrm{R}^{2}$ of .58, and a standard deviation of the residual of 34.1 
percent. A one percentage point rise in the median premium is associated with a 1.4 percent rise in the $\mathrm{S} \& \mathrm{P}$ index. A similar pattern emerges from examining the correlation between the median discount and the price/dividend ratio of the $\mathrm{S} \& \mathrm{P}$ composite.

Figure 5

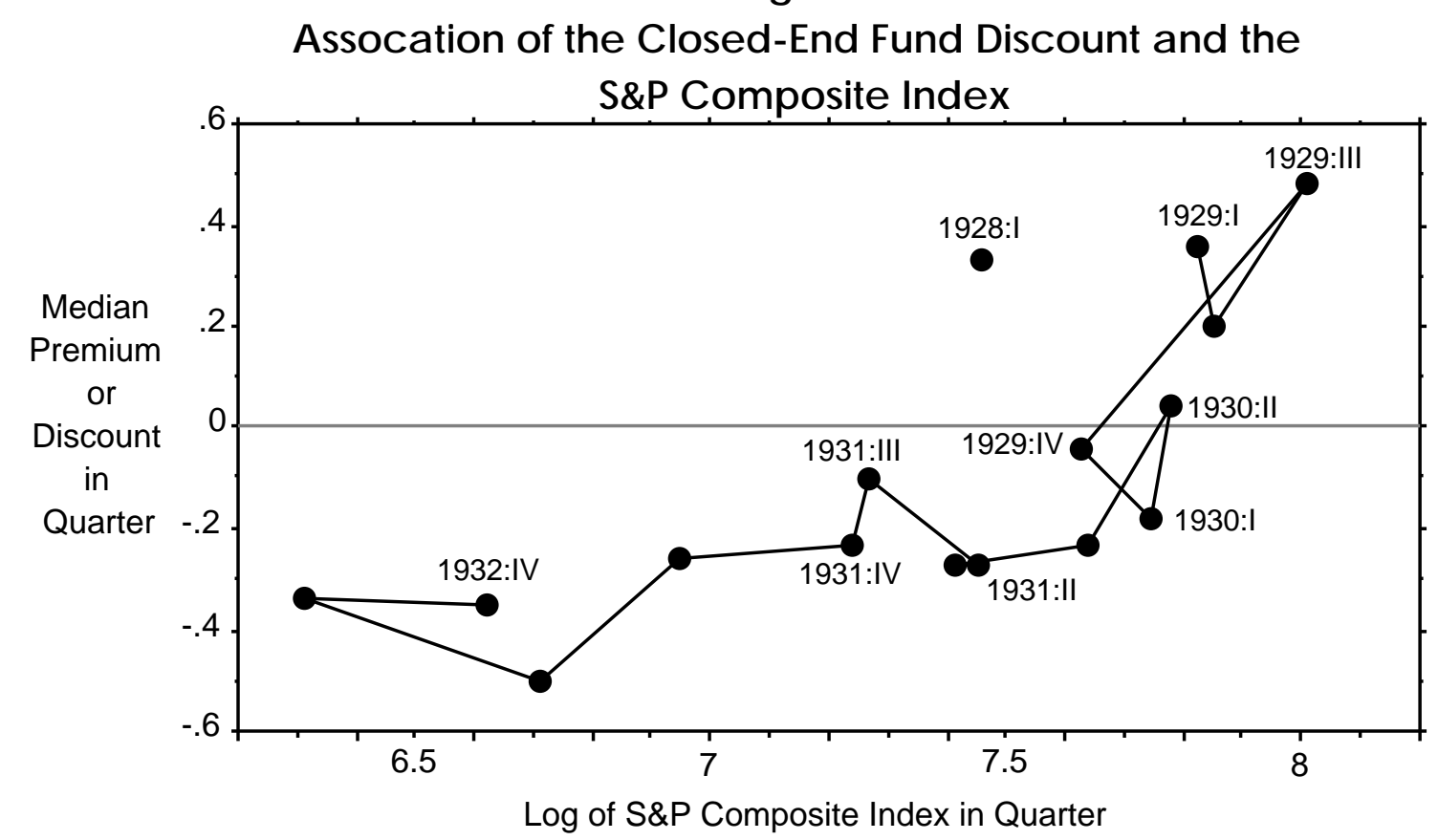

Regressing the log price/dividend ratio on the median discount over 1929-32 yields an $\mathrm{R}^{2}$ of .69, a slope coefficient of .77 (with a t-statistic of 5.4), and a standard error of the residual of 15 percent. The evidence that stock prices move together with closed-end fund premia is not consistent with standard explanations of the closed-end fund puzzle. The evidence supports the view that individual investor sentiment may affect stock prices and not just closed-end fund premia. ${ }^{2}$ The question then is how much of the stock price rise in 1929 could be attributed to overpricing?

If we could assume that fundamentals over this time period were relatively constant or slowlychanging, or that fundamental values were proportional to dividends, then we could use the correlation between the median closed-end fund discount and stock prices or price/dividend ratios to judge the extent of overvaluation in the summer of 1929. But this assumption does not appear plausible during the onset of the Great Depression, for there is every reason to believe that fundamentals were volatile around the end of the

2In the post-1960 period, when individual investors become less important in trading larger stocks but still important in trading small stocks, closed-end fund premia move together will small stocks. See Lee et al. (1990). 
1920's. We therefore turn to the Barsky and De Long (1990) assessment of how rational estimates of fundamental values shifted and show that the median closed-end fund discount has a very high correlation with those movements in stock prices that are unaccounted for by movements in that estimate of fundamentals.

\section{Barsky De Long-Based Measure of Investor Sentiment}

Barsky and De Long $(1989,1990)$ note that large swings in U.S. real stock prices over the twentieth century followed a relatively simple pattern. The coefficient of a regression of low frequency changes in log prices on low frequency changes in log real dividendsis around 1.5. In the twentieth century decades of rising dividends have seen stock prices rise more than proportionately.

Barsky and De Long argued that such a pattern in large swings can be accounted for if the expected future growth rate of dividends were positively correlated with past dividend growth. Such an expectation of future dividend growth would be rational if the dividend growth rate were subject to both transitory and persistent shocks. Barsky and De Long present a model in which expectations of future dividend growth for the $S \& P$ composite index are a geometric weighted average of past dividend growth rates:

$$
g_{t}=\sum_{i=0}^{\infty}(1-\theta) \theta^{i}\left(\Delta d_{t-i}\right)
$$

with the parameter $\theta$ near one. The warranted value of the $\mathrm{S} \& \mathrm{P}$ composite index is then:

$$
P_{t}=\frac{D_{t}}{r_{t}-g_{t}}
$$

This process for dividends fits the decade-to-decade swings in the stock market relatively well.

In Barsky and De Long's model, investors extrapolate growth rates of dividends. Small changes in present dividends can thus have extremely large consequences for valuation. This measure of fundamentals is extremely volatile. For this reason, it fits aggregate stock market movements at low frequencies much better than do measures that assume stationary dividends or dividend growth rates (Shiller, 1990). In addition, the Barsky and De Long (1990) measure of "fundamentals" accounts for 70 percent of the twentieth century variation in the year-to-year January S \& P composite index.

An alternative interpretation of the Barsky-De Long model is that dividend growth rates are not subject to persistent shocks, but rather investors overreact to news and therefore dividend innovations lead to share 
price changes higher than those warranted by the news. Barsky and De Long's warranted value attributes a larger share of stock price movements to fundamentals than may be appropriate. However, the Barsky-De Long measure of fundamentals captures only the long swings in stock prices: it does a poorer job at fitting within year and especially month-to-month variation. Barsky and De Long are agnostic about the source of these additional fluctuations. Here we assume that shifts in the difference between the S \& P index and the BDL measure of fundamentals reflect shifts in investor sentiment and examine their correlation of this estimate of investor sentiment with the average premium or discount on closed-end funds.

Figure 6 plots monthly average values of the S\&P composite nominal price and of the BDL fundamental from January 1925 to January 1933. Barsky and De Long (1990) calculated their fundamental as of January only. We have calculated monthly values of the BDL fundamental setting the current dividend equal to a three-month centered moving average of dividends on the S\&P composite as reported in Cowles (1938). Note that the Barsky-De Long fundamental is almost as volatile on a month-to-month and quarter-toquarter basis as is the S\&P composite. The end of the 1920's and the beginning of the 1930's saw much larger short-run changes in dividends than has been the rule since World War II.

Figure 6

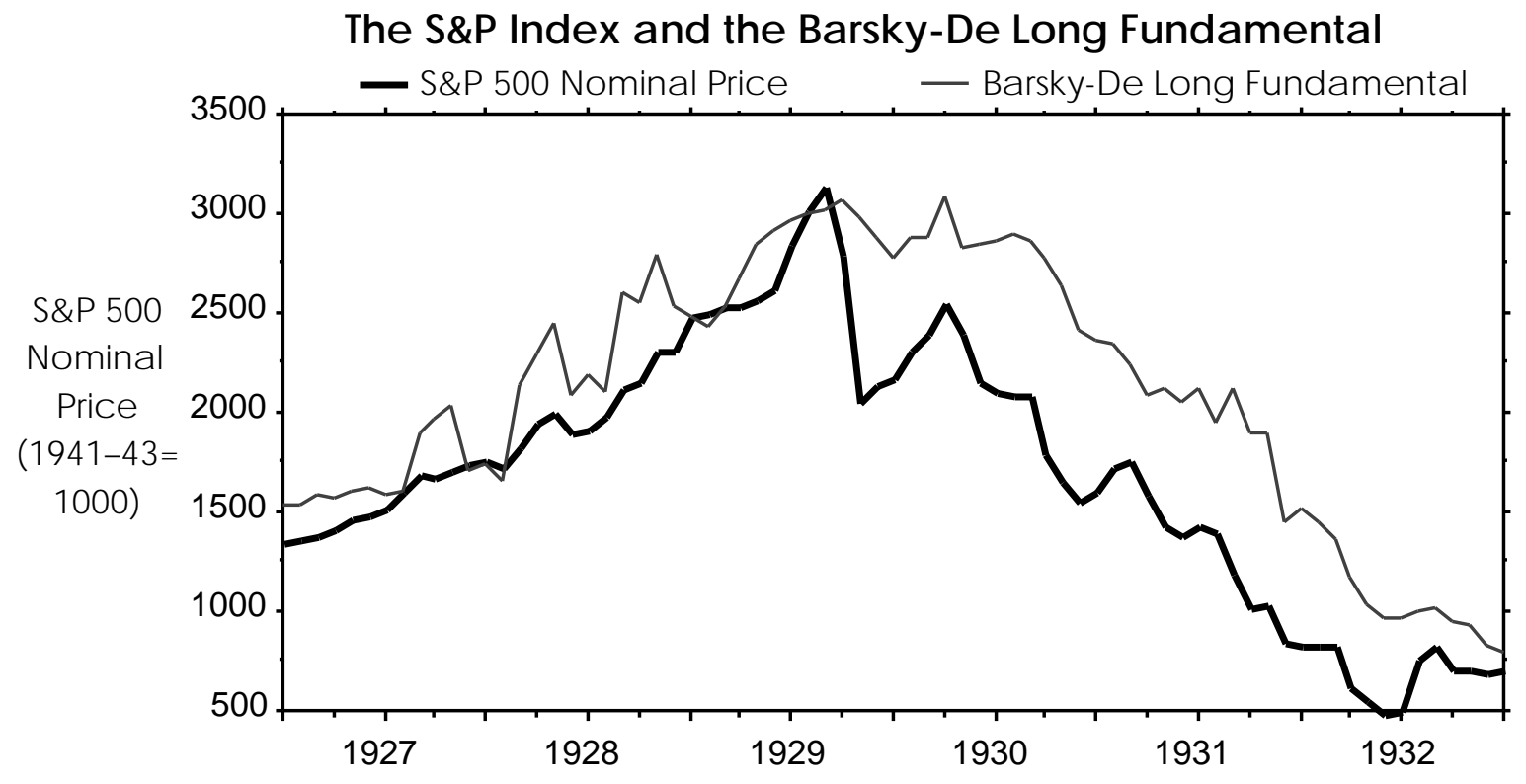

Estimated fundamentals rise throughout the bull market of the 1920's as real dividends grow and their rate of growth increases. The nominal value of the Barsky-De Long fundamental reaches its peak in 1930. 
Thereafter deflation lowers the fitted nominal for a constant real fundamental. The fall in real dividends as the economy slides into the Depression reduces the real fundamental value as well.

The difference between the S\&P stock index and the Barsky-De Long fundamental can be read off of figure 6. We call this difference between the price and Barsky and De Long's fundamental estimate the "BDL sentiment index." Importantly, this measure of investor sentiment has been constructed independently of and with no reference to the premium on the typical closed-end fund. In 1928 and early 1929 the BDL index is near zero, it then rises during the third quarter of 1929 and crashes with the market afterwards. The BDL index remains negative during the early 1930's.

Figure 7

Assocation of the Closed-End Fund Disc ount and the BDL Sentiment Index

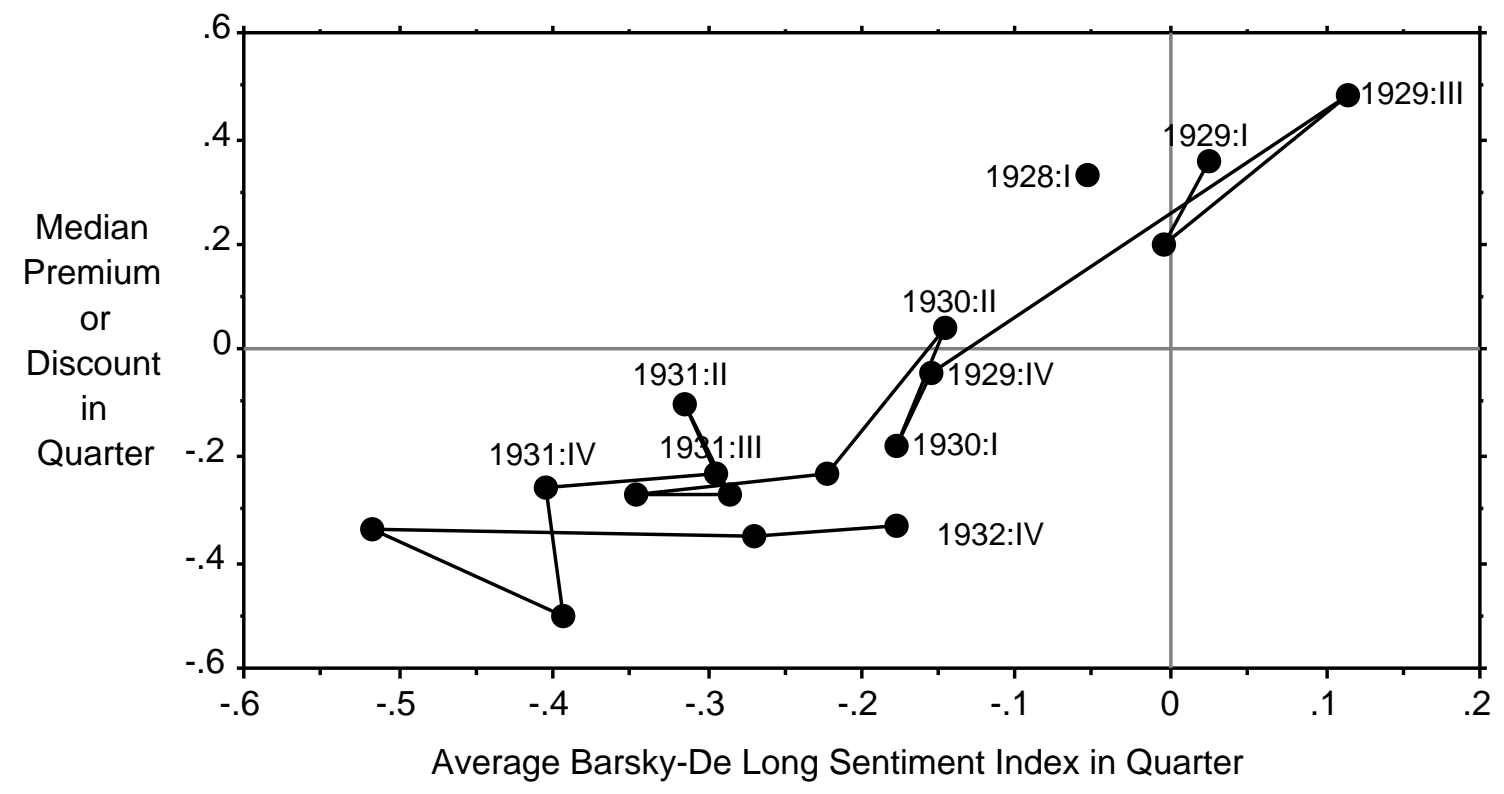

Figure 7 plots the median premium on closed end funds against the BDL sentiment index. ${ }^{3}$ There is a high positive correlation between the two. Regressing quarterly median premia on quarterly averages of the sentiment index from 1931:I through 1932:IV produces an $\mathrm{R}^{2}$ of .77, a standard deviation of the residual of 7.6 percent, and a slope coefficient of .47 (with a t-statistic of 6.52). Each one percent shift in the median closed-end fund premium is associated with a .47 percent shift in the $\mathrm{S} \& \mathrm{P}$ composite index relative to the

\footnotetext{
${ }^{3}$ The median premium is calculated quarterly. During 1929 especially we have too few observations to obtain good estimates of monthly typical premia and discounts.
} 
BDL fundamental. The fit between the Barsky-De Long sentiment index and the median closed-end fund discount is much tighter than the fit between the raw S\&P and the discount—suggesting that at least some of the large residual variance when stock prices were regressed on the discount springs from shifts in fundamentals that were not correlated with shifts in sentiment as captured by the median premium.

Using Lee et al.'s estimate of the average closed-end fund discount of $15 \%$ as the level at which investors are neither excessively optimistic nor excessively pessimistic, we can calibrate the absolute level of the stock market. Our estimates suggest that stock market mispricing in this period is about half of the deviation of the closed -end fund premium from -15\%. In July 1929 the typical closed-end fund premium is about $45 \%$, and thus $60 \%$ above its average post-1960 level. The S\&P index then was approximately $30 \%$ above the level it would have reached had the closed-end fund discount been at its "normal" level. We therefore attribute approximately $30 \%$ of the S\&P composite's value in the summer of 1929 to overvaluation from excessive investor optimism.

If we assume that Barsky and De Long's estimate ascribes too high a share of stock price movements to shifts in fundamentals, then our estimate of the S\&P composite's overvaluation in the summer of 1929 is even higher. On the assumption that fundamental values are proportional to dividends, the .77 slope coefficient from the regression of the price/dividend ratio on the median fund discount and suggests an overvaluation of $45 \%$ in the summer of 1929 . On the assumption that fundamental values are approximately stationary from year to year, the 1.4 slope coefficient from the regression of the nominal price on the median discount suggests an overvaluation of $80 \%$. Economists like Shiller (1990) might argue that the true measure of fundamentals would produce results between these last two cases.

\section{Some Real Effects of Mispricing}

The last years of 1920's saw an enormous expansion in the quantity of securities issued on the U.S. capital market. In 1928, three billion dollars each of stocks and bonds were issued, and in 1929 six billion dollars of stocks and two billion dollars of bonds were issued. Between 1925 and 1929, gross fixed investment ran at a constant rate of eleven billion 1929 dollars. Stock financing is thus an unusually important source of funds during this period-as one would expect if managers believed that their equity was overpriced. Not all equity issues, however, financed productive investment. Some of these issues were refinancing issues (calling of bonds); perhaps two billion dollars of new issues in each of 1928 and 1929 was 
devoted to that purpose.

More important, in 1929 a large fraction of equity issues were closed end investment companies.

Figure 8 plots the time series of the volume of new issues of all stocks and non-closed-end-fund stocks. The figure shows a peak 800 million dollar issue of new stocks in May of 1929, which largely reflected refinancing of bonds by utilities. The figure also shows that closed-end funds were a significant portion of new financing at the end of 1928 and the beginning of 1929.

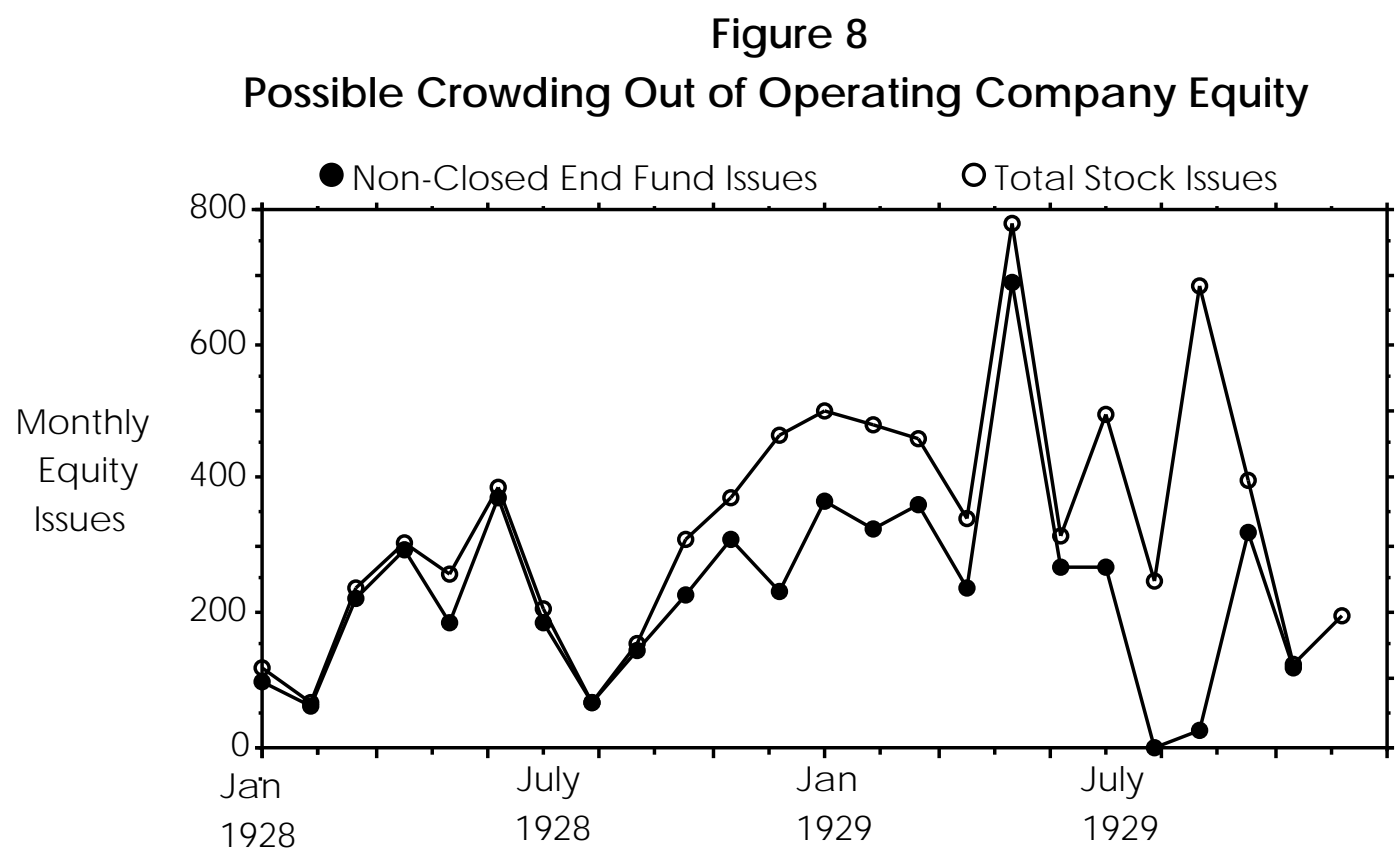

Perhaps most interestingly, the figure shows that closed-end funds dominated new stock issues in the summer and early fall of 1929, displacing other stocks completely in June and July. ${ }^{4}$ At the stock market peak, most of equity financing was closed-end fund financing. One interpretation of this result is that closedend fund issues crowded out new stock issues in this period. This finding raises the possibility that the overpricing of closed-end funds in the summer of 1929 reduced corporate access to capital. The normative significance is ambiguous. Reducing corporate access to capital and therefore possibly investment might cause good projects not to be undertaken and so reduce welfare. But if stock market bubbles lead to inefficiently cheap capital and therefore cause fundamentally unproductive projects to be pursued, displacing

\footnotetext{
${ }^{4}$ There is a seasonal pattern to new stock issues. On average during the 1920's new issues during July-September occur at half the rate of the other three quarters of the year. The third quarter of 1929, however, saw a very large volume of new issues, many of which were for closed-end funds.
} 
these projects raises welfare.

\section{The Approach of the Great Depression}

A strong tradition, which includes Friedman and Schwartz (1963), argues that it was not the speculative overvaluation but the government's reaction to it that brought on the Great Depression. Hamilton (1986) and Miron (1990) have recently argued that the Federal Reserve over 1927-29 pursued much more contractionary policies than were reasonable given the state of the real economy. The Federal Reserve believed that it should be in the business of restricting the rise in stock prices by imposing high interest rates and restricting credit. The Federal Reserve feared that if it did not do so, the bubble might be followed by a bust and a recession.

These policies of high interest rates and little credit expansion had an effect: economic activity reached a peak in the summer of 1929, and then started downward. The Federal Reserve Board, fearing that too easy money might restart a speculative bubble and set the stage for an even worse crash in the future, restricted the Federal Reserve Bank of New York's instinct to reduce interest rates and provide more liquidity in the fall of 1929. Miron (1990) argues that the Federal Reserve's fear of a depression brought on by a speculative crash led it to try to moderate stock price rises, but that attempts to curb the stock market with tight money played a key role in bringing on the depression that it had hoped to avoid.

\section{Conclusion}

There are few cases in which economists can observe fundamental values of securities directly. Closedend mutual funds provide one of those cases: their fundamental values are simply the net asset values of their portfolios. In this paper we have used the difference between prices and values of closed-end funds as a measure of investor sentiment.

We are confident that the same investor sentiment factor that leads to swings in closed-end fund prices in excess of the swings in their underlying values drives irrational swings in stock prices as well. We can conceive of situations in which stock prices accurately reflect fundamental values even thought closed-end funds exhibit substantial premia: rational arbitrageurs might be unable to drive the prices of closed-end funds to their true values because of an inability to sell short even though they drive the prices of stocks-which they can sell short-down to fundamentals. But we cannot conceive of a situation in which stock prices accurately reflect fundamental values and in which closed-end funds alternately sell at premia and discounts 
from their net asset values. Deviations of closed-end fund prices from values create opportunities for liquid investors with long time horizons to earn nearly-riskless excess returns. It is hard to see how the prices of closed-end funds could provide such arbitrage profit opportunities without also believing that such arbitrage profit opportunities exist in the prices of stocks in general as well.

In the late 1920 's, in contrast to previous and subsequent patterns, closed-end funds sold at large premia. We interpret these premia as a sign that investors in closed-end funds were overoptimistic: at the peak in the summer of 1929 , they appear willing to pay perhaps 60 percent more than post-World War II experience would suggest is the "normal" relative price of a closed-end fund. Such a substantial overpricing of an asset with observable fundamentals suggests that other assets might be selling at prices above fundamentals as well. The evidence from closed-end funds suggests that the stock market was substantially overvalued in the summer of 1929; our crude estimate is that the S\&P composite was at least 30 percent above fundamentals. 
Appendix: Pre-1930 Observations of Closed-End Fund Premia and Disc ounts

\begin{tabular}{|c|c|c|c|c|}
\hline Fund & New Issue? & Date* $^{*}$ & $\begin{array}{c}\text { Premium } \\
\quad \text { or } \\
\text { Discount (\%) }\end{array}$ & Source \\
\hline Investors' Equity Company & & 1927.91 & 71 & Keane/NYT* \\
\hline General Public Service Corp. & & 1928 & -12.5 & CFC $^{*}$ \\
\hline Chain Store Investment Corp. & & 1928 & 47.1 & Baker Higgins Collectic \\
\hline Continental Securities Corp & & 1928.25 & 19 & Keane/NYT \\
\hline Investors' Equity Company & & 1928.91 & 166 & Keane/NYT \\
\hline American, British, and Continental Corp. & & 1929 & 138 & Keane/NYT \\
\hline Chain Store Investment Corp. & & 1929 & 52.8 & Keane/NYT \\
\hline General American Investors & & 1929 & 233 & Keane/NYT \\
\hline General Public Service Corp. & & 1929 & -4 & CFC \\
\hline Shawmut Association & & 1929 & 0 & Keane/NYT \\
\hline Capital Administration Company & & 1929 & 1235 & Keane/NYT \\
\hline $\mathrm{AES}^{*}$ & & 1929 & -25.246 & Authors' calculations \\
\hline Tri-Continental & New Issue & 1929.08 & 13 & CFC/NYT \\
\hline AES & & 1929.08 & -28.152 & Authors' calculations \\
\hline National Securities Investment Company & New Issue & 1929.1 & 0 & CFC/NYT \\
\hline Chicago Corp & New Issue & 1929.12 & 36 & CFC/NYT \\
\hline Standard Investing Corporation & & 1929.16 & 84.7 & Keane/NYT \\
\hline Chain and General Equities Corp & & 1929.17 & 25 & CFC/NYT \\
\hline AES & & 1929.17 & -13.016 & Authors' calculations \\
\hline AES & & 1929.25 & -14.154 & Authors' calculations \\
\hline AES & & 1929.33 & -19.754 & Authors' calculations \\
\hline Mayflower Associates & New Issue & 1929.39 & 13 & CFC \\
\hline Investors' Equity Company & & 1929.41 & 54 & CFC \\
\hline American-European Securities & & 1929.41 & -22.4 & CFC/NYT/Keane \\
\hline Union-American Investing Company & & 1929.41 & 32.1 & CFC \\
\hline AES & & 1929.42 & -21.527 & Authors' calculations \\
\hline Mayflower Associates & & 1929.47 & 20 & CFC \\
\hline Shawmut Association & & 1929.49 & -10.7 & CFC \\
\hline General Public Service Corp & & 1929.49 & 34.1 & CFC \\
\hline United Founders Corporation & & 1929.49 & 110 & CFC \\
\hline U.S. and International Securities Corp. & & 1929.49 & 212.26 & CFC \\
\hline Power and Light Securities Trust & & 1929.49 & 6.1 & CFC \\
\hline AES & & 1929.5 & 6.475 & Authors' calculations \\
\hline American-European Securities & & 1929.53 & 11.9 & CFC \\
\hline Tri-Continental Corp. & & 1929.58 & 29.18 & $\mathrm{CF}$ \\
\hline Shenandoah Corp & New Issue & 1929.58 & 103 & CFC/NYT \\
\hline Interstate Equities & New Issue & 1929.58 & 25 & CFC/NYT \\
\hline AES & & 1929.58 & 25.196 & Authors' calculations \\
\hline Blue Ridge Corp & New Issue & 1929.64 & 46 & Keane/NYT \\
\hline Investors' Equity Company & & 1929.64 & 276.6 & CFC \\
\hline American Equities & New Issue & 1929.64 & 8 & Keane/NYT \\
\hline Prudential Investors & & 1929.66 & 18 & CFC \\
\hline Standard Investing Corporation & & 1929.66 & 48.4 & \\
\hline Second National Investors & & 1929.66 & 151.99 & CFC \\
\hline Shawmut Bank Investment Trust & & 1929.66 & 8 & CFC \\
\hline American Equities Corp & New Issue & 1929.67 & 8 & CFC/NYT \\
\hline AES & & 1929.67 & 21.729 & Authors' calculations \\
\hline Prince and Whitely & New Issue & 1929.68 & 18 & CFC/NYT \\
\hline Lehman Corporation & New Issue & 1929.71 & 16.5 & CFC/NYT \\
\hline Capital Administration Company & & 1929.75 & 263 & CFC \\
\hline Century Shares Trust & & 1929.75 & -5.3 & CFC \\
\hline General Public Service Corp. & & 1929.75 & 15.87 & CFC/Keane \\
\hline AES & & 1929.75 & 8.062 & Authors' calculations \\
\hline AES & & 1929.83 & -4.925 & Authors' calculations \\
\hline Graymur Corp. & & 1929.87 & & CFC \\
\hline AES & & 1929.92 & -8.737 & Authors' calculations \\
\hline General Public Service Corp. & & 1930 & 28 & CFC/Keane \\
\hline Shawmut Association & & 1930 & -33 & CFC \\
\hline Lehman Corporation & & 1930 & -18 & Keane/NYT \\
\hline
\end{tabular}


Blue Ridge Corp

Prudential Investors

Goldman-Sachs Trading Corp

AES

Power and Light Securities Trust

Lehman Corporation

AES

$\begin{array}{lll}1930 & -24.5 & \text { Keane/NYT } \\ 1930 & -30 & \text { CFC } \\ 1930 & -6.3 & \text { Keane/NYT } \\ 1930 & -18 & \text { Authors' calculations } \\ 1930.08 & -10 & \text { CFC } \\ 1930.16 & -14 & \text { Keane/NYT } \\ 1930.25 & -13.8 & \text { Keane/NYT }\end{array}$

*1929.00 = January 1, 1929; 1929.50 = July 1, 1929

AES-The American European Securities Corporation

CFC-The Commercial and Financial Chronicle

CF-Commerce and Finance

NYT-The New York Times

Keane-Keane's Manual of Investment Trusts 


\section{References}

Barsky, Robert and J. Bradford De Long (1989), “Why Have Stock Prices Fluctuated?” (Cambridge, MA: Harvard University mimeo).

Barsky, Robert and J. Bradford De Long (1990), "Bull and Bear Markets in the Twentieth Century," Journal of Economic History 50:2 (June 1990), pp. 1-17.

Becker, A.G., and Co. (1930), “The Investment Company," Keane’s Invesment Trust Monthly 1 (January), pp. $125-6$.

Cowles, Alfred et al. (1938), Common Stock Indices (Chicago: Cowles Associates).

De Long, J. Bradford, Andrei Shleifer, Lawrence Summers, and Robert Waldmann (1990), "Noise Trader Risk in Financial Markets," Journal of Political Economy (August).

Dice, Charles (1929), New Levels in the Stock Market (New York: McGraw Hill).

Fisher, Irving (1930), The Stock Market Crash—and After(New York: Macmillan).

Friedman, Milton, and Anna Jacobson Schwartz (1963), A Monetary History of the United States (Princeton, N.J.: Princeton University Press).

Galbraith, John Kenneth (1954), The Great Crash (Boston, Mass.: Houghton Mifflin Co.).

Hamilton, James (1987), "Monetary Factors in the Great Depression," Journal of Monetary Economics 19, pp. 145-69.

Keane, Charles, ed. (1930-33), Keane's Investment Trust Monthly

Keane, Charles, ed. (1928-1930), Keane's Manual of Investment Trusts (Boston: Financial Publishing Company).

Kindleberger, Charles (1978), Manias, Panics, and Crashes: A History of Financial Crises (New York: Basic Books).

Krecker, Preston (1929-1931), "Investment Trusts," a weekly column in Commerce and Finance

Lee, Charles, Andrei Shleifer, and Richard Thaler (1990), "Investor Sentiment and the Closed-End Fund Puzzle" (Chicago, IL: University of Chicago mimeo).

Malkiel, Burton (1987), A Random Walk Down Wall Street (New York: W.W. Norton)

Miron, Jeffrey (1990), "Monetary Policy, Curbing Speculation, and the Origins of the Great Depression" (Cambridge, MA: NBER mimeo).

New York Stock Exchange, Committee on Stock List (1929), “Tentative Special Requirements for Listing Investment Trust Securities," reprinted in Keane's Investment Trust Monthly1 (November), pp 5-6.

Rappoport, Peter, and Eugene White (1990), "Was There a Bubble in the 1929 Stock Market?" (New Brunswick, N.J.: Rutgers University xerox).

Santoni, Gary, and Gerald Dwyer (1990), "Bubbles vs. Fundamentals: New Evidence from the Great Bull Markets," in Eugene White, ed., Crises and Panics: The Lessons of History (Homewood, N.J.: Dow Jones-Irwin).

Shiller, Robert (1990), Market Volatility (Cambridge, MA: M.I.T. Press).

Sirken, Joel (1975), “The Stock Market of 1929 Revisited: A Note,” Business History Review 49, pp. 233- 
41.

Standard and Poor's Corporation (1984), Securities Price Index Record (New York: S\&P).

U.S. Congress, House of Representatives, Committee on Banking and Currency (1938), Investment Trusts and Investment Companies (Washington, DC: GPO).

White, Eugene (1990a), "When the Ticker Ran Late: The Stock Market Boom and Crash of 1929," in Eugence White, ed., Crises and Panics: Lessons of History (Homewood, N.J.: Dow Jones-Irwin).

White, Eugene (1990b), "The Stock Market Boom and Crash of 1929 Revisited," Journal of Economic Perspectives 4:2, pp. 67-83.

Wigmore, Barrie (1985), The Crash and Its Aftermath (Westport, Conn.: Greenwood Press). 